\title{
Opportunities and Barriers to the Development of Poland in the Field of Renewable Energy Sources as Compared to the European Union
}

\author{
Robert Muszyński, Katarzyna Kocur-Bera* \\ University of Warmia and Mazury in Olsztyn, Poland
}

Received 03 February 2020; accepted 06 April 2020

\begin{abstract}
Today, almost all of civilisation is based on energy. To a large extent, energy is being continuously acquired from non-renewable raw materials deposited in the Earth's crust. Renewable sources provide alternative, infinite energy resources, particularly solar radiation, wind power and water movement. The Paris Agreement envisages the complete abandonment of fossil fuels by the year 2050 for all EU Member States. From a technical point of view, a complete transition to renewable energy sources (RES) is very difficult to achieve. In the case of Poland, the way to $100 \%$ RES is longer and more complex than in most EU countries. The main purpose of the conducted analysis was to thoroughly assess the possibilities for obtaining energy from inexhaustible sources as well as the benefits of various procedures in order to develop an optimal set of solutions. The aim of the presented study is to indicate the possibilities for the development of construction investments in the field of renewable energy sources that have an inseparable impact on spatial management. To achieve this aim, the method of research of the available literature and legislation was applied.
\end{abstract}

Keywords: renewable sources, natural energy, climate change, land management.

\section{Introduction}

Nowadays, the world is struggling with increasing global warming. Rising temperatures of the oceans and the atmosphere, decreasing snow and ice caps, rising ocean levels and increasing greenhouse gas concentrations in the atmosphere indicate serious climate change. Today, humans are faced with the great challenge of meeting the growing energy needs while inhibiting global warming and the depletion of natural resources (Janiszyn et al., 2019).

Mainly due to the combustion of fossil fuels, the concentrations of carbon dioxide, methane and nitrogen oxide in the atmosphere have risen by $40 \%$ compared to the pre-industrial era (Rabe, 2017). In the years 1951-2010, greenhouse gases contributed to an increase in global average temperature by $0.5-1.3^{\circ} \mathrm{C}$ (IPCC, 2013). The world is increasingly struggling with heat waves and heavy rains (Kocur-Bera, 2018). According to current research, global temperatures will be higher by $15 \%$ than those assumed by the Intergovernmental Panel on Climate Change, IPCC) (Barke, 2018). According to the Global Footprint Network's report, people used their energy resources as intended for the entire 2018 in less than 7 months (GFN, 2019).

Further greenhouse gas emissions will cause progressive warming and climate change. The European Union countries are faced with the task of developing and reforming the current energy policy which must be ambitious and long-term while being thoughtful and reasonable at the same time (Frankowski, 2017). As part of the Union's energy market integration, many barriers are emerging which limit the pursuit of the set objectives, inter alia the Member States' different approaches to environmental protection. The lack of energy source diversification has been identified as one of the major challenges (Janiszyn et al., 2019). On 17 January 2018, the European Parliament adopted new targets with regard to the use of renewable energy sources by the year 2030. MEPs declared that the share of energy from renewable resources should be increased to at least $35 \%$.

The aim of this study is to summarise the energy policies of Poland and the European Union which specify solutions to the increasing energy needs and actions to prevent climate change. It presents the EU Member States' struggles and achievements in preventing climate change on our planet. Moreover, it analyses Poland's barriers, possibilities and goals when increasing the share of renewable energy sources in the Union's summary of energy consumption in electrical power engineering, heat engineering and transport. Poland's potential is presented based on the example of the commune of Kisielice which, as early as in 2015, achieved energy self-sufficiency. The article was drawn up based on a review of the available literature and press materials, as well as on studies published by the

\footnotetext{
*Corresponding author. E-mail: katarzyna.kocur@uwm.edu.pl
} 
Ministry of the Environment and Ministry of Energy and online statistical databases concerning the RES policy in the EU and Poland.

\section{Achievements and objectives of the energy transition}

In view of the energy crisis and environmental protection, there is a growing interest in new, unconventional energy sources and generation technologies to provide an alternative to the depleting resources. The primary energy source on Earth is solar radiation. Primary sources also include the reactions of the heavy element breakdown in the Earth's core. Solar radiation can be used either directly to generate energy by photovoltaic cells or indirectly through the formation of air circulation movements that are used by wind power plants. Hydroelectric power plants use the phenomenon of water circulation in the air, which is initiated by the heating of surface waters. The energy from the Sun is essential for the photosynthesis process, and the energy stored in organic compounds can be used in biomass, biofuel and biogas-fired power plants (Dmowski \& Rosłaniec, 2010). It is interesting to note that the amount of energy reaching the Earth is enormous and much greater than all renewable and non-renewable energy sources put together (Figure 1) (Bartosik, 2007).

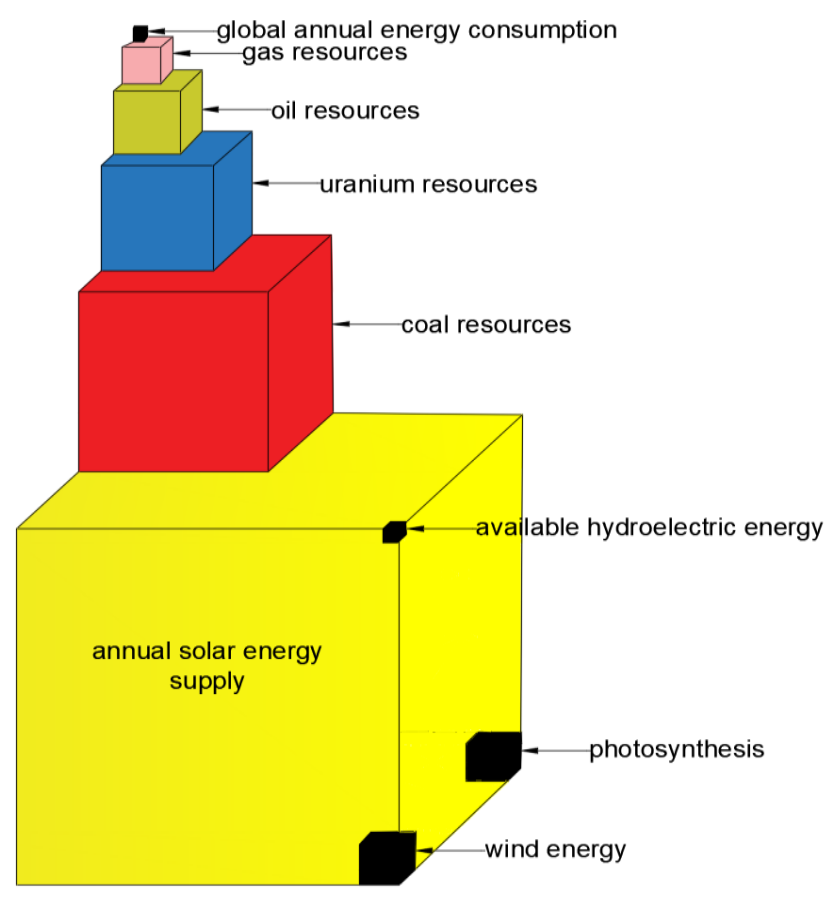

Figure 1. A comparison of the amount of solar energy reaching the Earth to other resources (source: Author's research based on Dmowski \& Rosłaniec, 2010)

Global energy transition is mainly based on energy derived from renewable sources. The transition process is shown as a shift from the traditional path of energy supplies to inexhaustible energy, both at a global, national and individual household level (Smil, 2010). Scientists argue that not only are changes in the fuel used important but that systems of socio-economic and political relations are of significance as well (Miller et al., 2013). The energy transition is due to several reasons:

- the resources of fossil fuels are decreasing, and their extraction involves increasing costs;

- increased interest in renewable energy sources contributes to technology development;

- increased public awareness and the recognition of the RES potential;

- certain political leaders' determination (Manwell et al., 2009; Popkiewicz, 2016).

It is the leaders of highly-developed countries in the EU, e.g. Denmark of Germany, that are primarily characterised by determination. However, China and African countries are increasingly developing in the RES sector as well.

In this year's CCPI, Poland, compared to other countries, performs very poorly. It is the worst-performing country in the EU and in the overall ranking, it ranks 50th among all the countries included in the ranking. Poland has a very low rating in all categories including that of renewable energy. In terms of climate policy, Poland's rating is very low as well. Scientists criticise the energy plan for the year 2040 because it fails to mention emission reductions. New lignite and hard coal mines contribute to an increase in greenhouse gases released to the atmosphere. Experts do not approve of Poland's opposition to the achievement of emission neutrality by the year 2050 . The only positive forecast 
is the first signs of turning points in climate policy in the form of the government's commitments to increase the renewable energy share. Public awareness is increasing while the costs of environmentally-friendly technologies are decreasing. Increased pressure to regulate the climate and energy framework in the EU is forcing the government to reform the existing policy. In 2019, the government created a Ministry of Climate. Having analysed the government's commitments to increase the share of renewable energy in total energy consumption, it can be concluded that Poland may start catching up with other EU countries in the coming years. The graph below shows the share of renewable energy sources in the EU's summary of energy consumption in Poland and the EU.

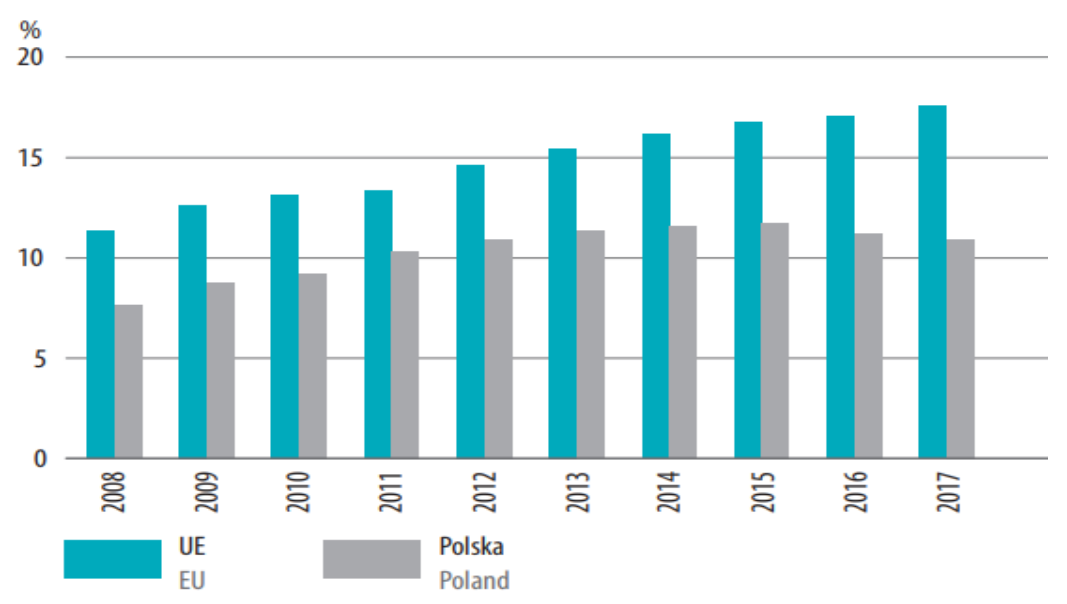

Figure 2. Share of renewable energy in final gross energy consumption (source: Główny Urząd Statystyczny, 2019)

As shown in the figure above (Figure 2), the share of renewable energy sources in the EU's summary of energy consumption in electrical power engineering, heat engineering and transport in the EU has been increasing year-onyear. In 2017, this index was $17.5 \%$ and was higher by 0.5 percentage points from the level achieved in 2016 . To achieve the assumed target of the $20 \%$ level of RES in energy consumption in 2020, an increase of 2.5 percentage points is still required.

According to the data, in Poland in 2017 the share of renewable energy in the consumption of electricity and thermal energy and in the transport amounted to $10.9 \%$. This index is lower than it was in the years $2013(11.4 \%)$, 2014 (11.5\%), 2015 (11.7\%) and then the level achieved in 2016 (11.3\%). Statistical data show that Poland is moving away from achieving the target of the renewable energy share in the national energy mix. If a country fails to achieve the national RES target set for 2020, the costs will amount to billions of PLN. Failure to meet the RES target indicates the necessity to obtain green energy from the so-called statistical transfers, i.e. the purchase of "virtual" RES energy from the countries which have produced a surplus.

As early as in 2017, the assumed levels of the renewable energy share in national energy mixes were achieved by 11 countries, which include Bulgaria, the Czech Republic, Denmark Estonia, Croatia, Italy, Lithuania, Hungary, Romania, Finland and Sweden. The countries that are in a situation similar to that of Poland also include the Netherlands, France, Ireland, the United Kingdom, Luxembourg and Belgium (Eurostat, 2019). Prepared by: (Gramwzielone.pl., 23.12.2019).

The EU's objectives as regards combating climate change and energy policy for the years 2020-2030 are presented in several directions. The new framework is supposed to address inter alia the following issues (European Commission, 2020):

- taking further measures to reduce greenhouse gas emissions so that a reduction by $80-95 \%$, compared to the 1990 levels, can be achieved by 2050;

- a reduction in energy prices, and the stabilisation of the Union's economy in view of the changing gas and oil prices;

- modernisation of the energy infrastructure;

- setting a target to reduce greenhouse gas emissions by 2030.

The new European Union energy strategy assumes that by 2030, the share of RES will be at a level of $32.5 \%$. Until 2030, the policy does not impose specific objectives in a particular country. A review of the country's achievements in the field of renewable energy generation will be carried out in 2023. The energy strategy is intended to ensure the implementation of all regulations adopted at the end of 2018 in Regulation on Energy Union Governance. Pursuant to Regulation (EU) 2018/1999 of the European Parliament and of the Council of 11 December 2018 on the Governance of the Energy Union and Climate Action, EU Member States are required to prepare national climate and energy plans for the years 2021-2030. Countries are to indicate, in their studies, how they are going to increase the share of renewable energy. In the National Energy and Climate Plan, the Ministry of Energy set the following objectives for Poland: 
- an increase in the RES share in energy consumption up to $21 \%$;

- an increase in the RES share only in electricity of up to approx. 27\%;

- an increase in the RES share in heat engineering and refrigeration engineering by 1-1.3 percentage points;

- an increase in the RES share in transport up to $14 \%$.

These objectives are not too great a contribution to the EU's objectives. The adopted RES share in energy consumption in 2020 was intended to amount to $15 \%$, and it will be possible to achieve this level as late as in 2022 . In view of the progress made so far in the development of RES, the Ministry of Energy considered the national commitment to be ambitious (Ministry of Energy, 2019).

\section{Analysis of the RES policy}

Compared to other EU Member States, Poland has a high energy potential and significant advantages of a complete transition to RES by 2050. It is among the top ten EU countries with the potentially highest benefits. The forecasted energy acquisition in Poland is supposed to originate (by more than 75\%) from offshore and onshore wind power generation, and the remaining portion of energy from solar collectors and power plants. These proportions are slightly different in the EU. In countries with high solar exposure, the main potential energy source by 2050 include collectors and solar power plants; these include the Mediterranean countries, i.e. Croatia, Romania, Greece and Bulgaria, where the solar exposure during the year ranges from 1500 to 2000 kilowatt-hours. Poland is situated in a zone with solar exposure of less than $1300 \mathrm{kWh}$. In countries with good access to marine waters, offshore wind power plants have a large share of total energy acquired from RES. The President of the Polish Wind Energy Association believes that Poland has one of the largest wind potentials throughout Europe. Over the next few years, the amount of electricity generated from wind energy may increase by $110 \mathrm{GW}$, of which $3.5 \mathrm{GW}$ generated in Poland (Gorczyca, 2011).

There are regions in Poland that do not differ from countries that are leaders in terms of renewable energy. According to the conducted research, in recent years Zachodniopomorskie Voivodeship has been the leader in electricity generation from RES. The share of electricity from RES in this voivodeship amounted to as much as $63.82 \%$. This case proves that in Poland, there are also possibilities for "green energy" to grow in strength and dominate energy acquisition from depleting resources. It is worth noting that Zachodniopomorskie Voivodeship generates electricity using almost exclusively wind installations. The second voivodeship in terms of RES share in electricity generation is the Kujawsko-Pomorskie with a result of $55.96 \%$, and almost $25 \%$ of the share is attributable to hydroelectric power plants. As shown in the figure below (Figure 3), north-western and central parts of Poland have the largest amounts of energy produced from renewable sources.

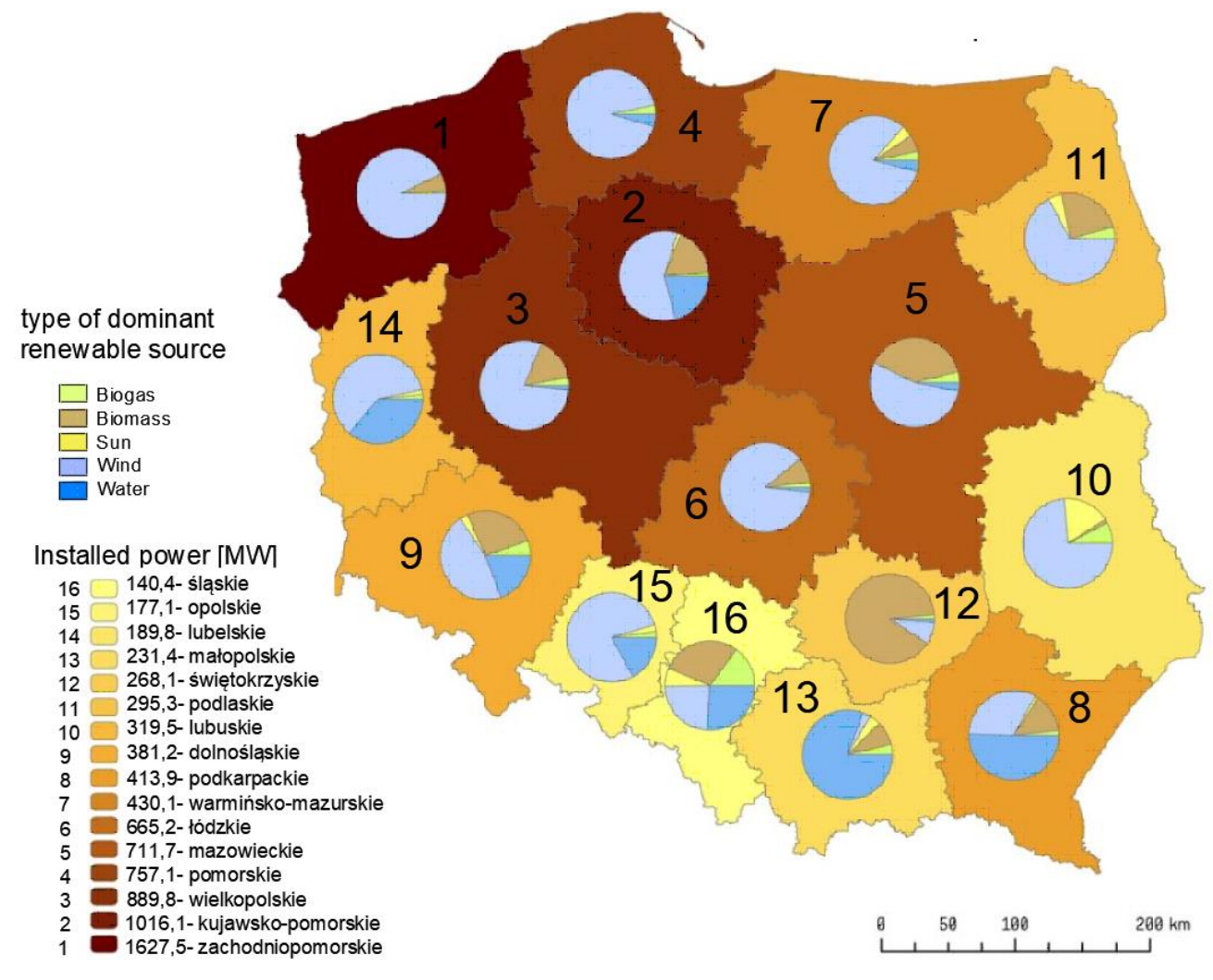

Figure 3. The installed capacity in renewable energy sources broken down by voivodeships (source: Author's research based on Piaskowska \& Lesińska, 2019) 
Poland has a diverse range of renewable energy resources which are still used to a small extent. What is more, there are numerous infrastructural, environmental and spatial limitations to the use of this potential. The work of estimating the potential of a particular area should be investigated at the local level (Ministry of the Economy, 2007).

Energy generated from renewable sources is, in principle, more expensive than that from conventional sources. Due to low prices of the energy carriers that are rooted in culture, the use of coal as the main energy fuel by many generations, as well as energy subsidies, the introduction of renewable sources is becoming much more difficult (Minister of the Environment, 2000). There are many more barriers which limit the development of RES. These can be characterised in four aspects: environmental, economic, social and legal and administrative (Deluga, 2007).

As regards hydroelectric power plants, environmental barriers mainly include the interference with the natural environment, i.e. river bed siltation, impact on fish populations, and changes in water level which result in landslides and abrasion of the banks. On the other hand, wind power generation poses a threat to birds, and adversely affects the landscape values. For the local population, wind turbines are a nuisance due to the noise and vibrations (Nowodziński \& Kościńska, 2016). The most significant barriers to the acquisition of energy from biomass include production oriented towards energy crops (monoculture cultivation) and the release of toxic and carcinogenic dioxins and furans during the combustion of biomass (Lewandowski, 2008). A major threat for a biogas plant is a lack of biomass, which can lead to the suspension of plant operation. Obtaining energy from solar radiation is not profitable in every region of Poland due to poor solar exposure during the year.

The economic barriers include very high costs of expenditure in relation to the financial benefits derived from renewable energy sources. The costs of the installations and equipment intended for energy generation and preliminary (e.g. land surveying) works are associated with high financial expenditure which can be recovered after a long period of use (Nowodziński \& Kościńska, 2016).

Examples of social barriers include the lack of proper education on the use of RES, the community's ignorance about the investment cycle costs, and the operating costs. This group of barriers also includes ignorance of the economic, social and environmental advantages associated with the implementation of investments in renewable energy. The main factors impeding the development of RES in Poland is the lack of formal and legal regulations. In Poland, there is no proper support for the development of, for example, photovoltaics. Legal and administrative procedures are lengthy and time-consuming (obtaining appropriate documents for the implementation of an investment may take as long as several years). Another major limitation to the development of RES is the hindered possibility for connecting these sources to the power grid. Despite the limitations in RES development, it is supported by the community. as they recognise a number of advantages at the local level. These include, inter alia, environmental benefits, financial benefits for the commune and new jobs in the RES sector.

It is a very good example that in Poland, despite the barriers, the development of RES is possible, and that impressive results can be achieved in the field of renewable energy. In the commune of Kisielice, the local community has made use of the potential of the areas they live in as well as the assistance received from the EU. This is an urban and rural commune located in Warmińsko-Mazurskie Voivodeship, with an area of $172.9 \mathrm{~km}^{2}$, with over 6,000 inhabitants. The commune of Kisielice is the first energy self-sufficient commune in Poland. The vast majority area is covered with forests, which explains the low population density. The commune comprises the centrally located town of Kisielice and 21 smaller localities (Frankowski, 2017). The agricultural character of the commune and its location in a favourable wind zone offer potential for the development of renewable energy sources (Lorene, 1996). As early as at the end of the 1990s, the communal government was seeking additional income in the alternative energy sector. The first step was the inclusion of wind turbines in the Commune Area Development Plan (Koprowiak, 2014b). After accession to the EU, subsidies rendered it possible to invest in renewable energy sources. Currently, there are 52 wind turbines with a total capacity of 94.5 MW are located in the community. This is one of the largest wind farms in Poland. There were no protests among the local community. The inhabitants were prepared for this investment at meetings and during information sessions. A straw-fired boiler with a total capacity of $6 \mathrm{MW}$ has been constructed as well. As a result, coal and oil boilers have been shut down, which has contributed to a reduction in greenhouse gas and pollutant emissions. In the commune of Kisielice, a municipal heat distribution network for approx. 230 inhabitants has been constructed. In 2013, the construction of a maize silage-based biogas plant was commenced. Moreover, street lighting has been upgraded, as mercury fittings have been replaced with sodium fittings, which reduced electricity consumption (Frankowski, 2017).

In the commune of Kisielice, more electricity is generated than consumed. Only under very unfavourable weather conditions is the use of domestic energy supplies necessary. The heat balance is slightly less yet it is still impressive. The Commune Mayor claims that the biomass-fired boiler and biogas plant satisfy $1 / 3$ of the commune's thermal energy needs. The investments made by Kisielice in RES have been noted in the international arena. In 2014, the commune won the main prize in the ManagEnergy competition organised by the European Commission.

The material benefits arising from renewable energy sources primarily take the form of property tax. As regards wind turbines, the tax is $2 \%$ of the installation value. Since 2006, in the commune of Kisielice, the receipts from real estate tax have been higher than receipts from agricultural tax. In the commune's budget for 2016, the income of almost PLN 3 million accounted for several percent of the commune's entire income. The yields from investments in renewable energy sources ensure budget stability and also contributed to subsequent investments from European Union 
funds. Investors sponsored many investments and got involved in infrastructural projects. Moreover, owners of the plots on which wind turbines have been constructed receive an income from the lease which amounts to approx. PLN 35,000 per annum. Farmers earn money from the supply of straw and maize to heating plants and biogas plants (Koprowiak, 2016).

There are many more advantages arising from investments in RES. The air quality in the commune has improved. $\mathrm{CO}_{2}$ emissions have decreased by 182,000 tonnes per annum, mainly through connecting $85 \%$ of buildings in the town of Kisielice to the heat distribution network and replacing furnaces in the heating plants. Public awareness of the benefits arising from RES has increased significantly. A positive image of energy policy, not only recognisable in Poland but also in Europe, has been created. Unlike other communes in Poland, the commune of Kisielice can serve as an example of the authorities' consistency of conduct and the inhabitants' favourable attitude towards renewable energy sources (Koprowiak, 2014a; Ruszczuk, 2015).

\section{Conclusions}

Investments in RES are intended to have a positive effect on the climate, development of clean technologies, new opportunities for research and technological progress, the development of a market of new services (related to management, infrastructure maintenance, energy advice and intermediation on the energy market) and spatial management. The European Union is introducing a climate and energy framework that the Member States are required to adhere to. Certain Member States are coping better than average with the introduction of renewable energy sources in the total consumption. These include Sweden, Denmark, Lithuania and Finland. In the Climate Change Performance Index list, Poland is in last place among all EU countries. In recent years, no significant investments in RES have been noted, which prevents the achievement of the assumed target of the $15 \%$ share of energy obtained from renewable sources in total consumption. According to forecasts, this level will be achievable as late as in 2022 (PEP2050, 2015).

Poland has great possibilities for the development of renewable energy sources. Wind energy, which is the most popular of all inexhaustible sources in the country, has considerable potential. It is estimated that when all energy is acquired from renewable sources, in Poland more than $75 \%$ will originate from onshore and offshore wind power plants. On the domestic market, even though there are increasing investments in photovoltaics, they are still insufficient. The entire investment process is very long and time-consuming; sometimes it lasts for several years. The lack of formal and legal regulations are one of the main factors impeding the development of RES in Poland. There are also numerous spatial and environmental constraints. Another barrier may also be the local community which may not have been sufficiently informed about the advantages and effects of investments in RES in the near vicinity. However, by starting from the lowest level and changing local policy, Poland can achieve a lot in the field of renewable energy and catch up with the EU countries that lead the way in this area.

The development model applied in the commune of Kisielice is not universal. It is reflected only in small communes of 5,000-10,000 inhabitants, with an agricultural character and low population density.

One of the most important European Union's objectives is the transition to a low-emission economy. A considerable pool of money has been allocated for the implementation of this project. When the commune of Kisielice invested in RES, they only used European Funds. A photovoltaic installation has been constructed and the heat distribution network has been expanded using funds from the budget of the regional programme for the WarmińskoMazurskie Voivodeship. Thanks to the "Human Capital" programme, the training of the commune inhabitants in RES has been conducted and paid for, and the "Infrastructure and Environment" programme has created a plan for a lowemission economy for the next seven years. In total, the commune invested almost PLN 17 million in RES, most of which was acquired from EU programmes. Thanks to these investments, carbon dioxide emissions in the commune have decreased by 182,000 tonnes per annum. Moreover, significantly less sulphur and dust have been released to the atmosphere.

The commune of Kisielice provides a model for the use of endogenous potential, and has undergone a positive energy transition. Based on this example, it can be concluded that RES can be a source of considerable income for local governments, and bring many benefits associated with an improvement in the environmental quality. RES also offers possibilities for creating local sales markets. The issues of local benefits are not, however, so obvious. The commune is growing considerably rich thanks to tax revenues; however, inhabitants of the localities covered by such investments do not experience significant benefits from their implementation.

\section{References}

Bartosik, M. (2007). Globalny kryzys energetyczny - mit czy rzeczywistość? Wybrane możliwości działań antykryzysowych w elektrotechnice. In X Międzynarodowa Konferencja "Nowoczesne urządzenia zasilajace w energetyce”, Zakopane.

Berke, J. (2018). Na Ziemi kończq się surowce do utrzymywania życia. Retrieved December 22, 2019, from https://businessinsider.com.pl/technologie/nauka/koncza-sie-zasoby-naturalne-ziemi-ostrzega-bankhsbc/s1w7cxj?fbclid=IwAR3ONg3Lr8d08kLiZyLZlfXXpI0_sgXIDXqf3gE1BbLPDk-YmMqaPRSQKrw

Communication from the Commission to the European Parliament, the Council, the European Economic and Social Committee, the Committee of the Regions and the European Investment Bank A Framework Strategy for a Resilient Energy Union with a 
Forward-Looking Climate Change Policy, $\operatorname{COM}(2015) 80$ final. Retrieved December 08, 2019, from https://eurlex.europa.eu/resource.html?uri=cellar:1bd46c90-bdd4-11e4-bbe1-01aa75ed71a1.0007.02/DOC_1\&format=PDF

Conclusions of the European Council on the climate and energy policy framework by 2030. (Year). EUCO 169/14. Brussels, 24 October 2014. Retrieved December 08, 2019, from https://www.teraz-srodowisko.pl/media/pdf/aktualnosci/336-KonkluzjeRady-24-10-2014.pdf

Deluga, W. (2007). Analiza korzyści, barier i następstw rozwoju alternatywnych źródeł energii na przykładzie energetyki wiatrowej. Zeszyty Naukowe Politechniki Koszalińskiej Wydziału Budownictwa i Inżynierii Środowiska, nr 23.

Dmowski, A., \& Rosłaniec, Ł. (2010). Odnawialne źródła energii- możliwości i ograniczenia w warunkach Polskich. Politechnika Warszawska.

European Commission. (2020). 2030 climate \& energy framework. Retrieved January 02, 2020, from https://ec.europa.eu/clima/policies/strategies/2030_en

Eurostat. (2019). Dane statystyczne dotyczace energii ze źródel odnawialnych. Retrieved December 28, 2019, from https://ec.europa.eu/eurostat/statistics-explained/index.php?title=Renewable_energy_statistics/pl

Frankowski, J. (2017). Transformacja energetyczna w Polskiej gminie. Skutki polityki lokalnej opartej o odnawialne źródta energii na przykładzie Kisielic, Wydawnictwo Uniwersytetu Jagiellońskiego.

Global Footprint Network (GFN). (2019). EU overshoot day living beyond nature's limits. Retrieved December 30, 2019, from https://www.footprintnetwork.org/

Główny Urząd Statystyczny (GUS). (2019). Wskaźniki zielonej gospodarki w Polsce 2019. Retrieved December 22, 2019, from https://stat.gov.pl/obszary-tematyczne/srodowisko-energia/srodowisko/wskazniki-zielonej-gospodarki-w-polsce2019,5,3.html

Gorczyca, M. (2011). Energia ze źródeł odnawialnych w Polsce na tle innych krajów Unii Europejskiej. Energetyka i Ekologia, 515-518. Retrieved December 14, 2019, from http://elektroenergetyka.pl/upload/file/2011/8/Gorczyca.pdf

International Panel on climate change (IPCC). (2013). Climate change 2013. The Physical Science Basis. Summary for policymakers, technical summary and frequently asked questions. Retrieved December 12, 2019, from https://www.ipcc.ch/site/assets/uploads/2018/03/WG1AR5_SummaryVolume_FINAL.pdf

Janiszyn, N., Hliwa, J., \& Rabe, M. (2019). Globalne zmiany klimatu a polityka energetyczna Polski i Unii Europejskiej. Nauka, badania i doniesienia naukowe 2019 (pp. 69-76).

Kocur-Bera, K. (2018). A safe space of rural areas in the context of the occurrence of extreme weather events - a case study covering a part of the Euroregion Baltic. Land Use Policy, 71, 518-529. https://doi.org/10.1016/j.landusepol.2017.11.013

Koprowiak, T. (2014a). Gmina samowystarczalna energetycznie. Retrieved December 08, 2019, from http://modanazdrowie.pl

Koprowiak, T. (2014b). To się opłaca. Wywiad z burmistrzem Kisielic, gdzie powstała biogazownia. Retrieved December 08, 2019, from http://samorzad.pap.pl

Koprowiak, T. (2016). Kisielice nie zapomniały o swoim dawnym burmistrzu Tomaszu Koprowiaku. Retrieved December 08, 2019, from http://kisielice.wm.pl

Lewandowski, W. (2008). Proekologiczne odnawialne źródła energii. WNT, Warszawa.

Lorenc, H. (1996). Struktura i zasoby energetyczne wiatru w Polsce. IMGW, Warszawa.

Manwell, J., McGowan, J., \& Rogers, A. (2009). Wind energy explained: Theory, design and application. Wiley, New York. https://doi.org/10.1002/9781119994367

Miller, C., Iles, A., \& Jones, C. (2013). Social dimensions of energy transitions. Science as Culture, 22(2), $135-148$. https://doi.org/10.1080/09505431.2013.786989

Ministry of Energy. (2019). National Energy and Climate Plan for 2021-2030; Objectives, targets and policies for action. Retrieved December 08, 2019, from https://www.gov.pl/web/aktywa-panstwowe/krajowy-plan-na-rzecz-energii-i-klimatu-na-lata2021-2030-przekazany-do-ke

Ministry of the Economy. (2007). Possibilities for the use of renewable energy sources in Poland. Warszawa 2007. Institute for Renewable Energy. Retrieved December 20, 2019, from https://www.ieo.pl/pl/raporty/60--18/file

Ministry of the Environment. (2000). Strategy for renewable energy development. Warszawa. Retrieved December 20, 2019, from http://www.access.zgwrp.org.pl/materialy/dokumenty/StrategiaRozwojuEnergetykiOdnawialnej/

Nowodziński, P., \& Kościańska I. (2016). Bariery inwestowania w odnawialne źródła energii (OZE). Wydawnictwo Społecznej Akademii Nauk, Warszawa, 235-245.

PEP2050. (2015). Draft Poland's Energy Policy until 2050. Retrieved December 20, 2019, from https://www.gov.pl/documents/33372/436746/DE_projekt_PEP2050_2015-08-03.doc/57c5150f-f50e-e8a7-6b2749c330ab9d4d

Piaskowska, A., \& Lesińska, M. (2019). Gdzie jest rewolucja energetyczna w Polsce powiatowej? SWECO.

Popkiewicz, M. (2016). Rewolucja energetyczna. Ale po co? Retrieved December 20, 2019, from https://smoglab.pl/rewolucja-energetyczna-ale-po-co/

Rabe, M. (2017). Analiza bieżącej sytuacji formalno-prawnej i rynkowej oraz uwarunkowań technicznych pod kątem wykorzystania i rozwoju odnawialnych źródet energii w województwie zachodniopomorskim. Regionalne Biuro Gospodarki Przestrzennej Województwa Zachodniopomorskiego, Szczecin.

Ruszczuk, R. (2015). To OZE postawito na pana Koprowiaka. Retrieved December 20, 2019, from http://infoilawa.pl

Smil, V. (2010). Energy transitions. History, requirements, prospects. Praeger, Westport. 